\title{
Support for restricting smoking at workplaces in developing countries: a survey of Peace Corps staff
}

\author{
Thomas R Eng, Seth L Emont, Theresa H van der Vlugt
}

\begin{abstract}
Objective To survey smoking behaviour and the attitudes of Peace Corps staff regarding restricting smoking at their workplaces in developing countries.

Design Anonymous postal survey of all full time Peace Corps staff (estimated $\mathbf{n}=900$ ) in 58 countries.

Subjects 652 full time staff who returned completed questionnaires; $73 \%$ were host country nationals from more than $\mathbf{5 0}$ developing countries.

Main outcome measures Smoking prevalence, support for a smoke-free workplace policy, and awareness of the adverse health effects of environmental tobacco smoke.
\end{abstract}

Results Overall, $81 \%$ of respondents supported a smoke-free workplace policy, including $78 \%$ of staff from developing countries, $67 \%$ of current smokers, and $68 \%$ of staff with lower educational levels. Significant differences in support for a smoke-free policy were found when staff were grouped by smoking status, country of origin (developing $v$ developed), years of formal education, and region of origin. In addition, $74 \%$ of staff were aware of the harmful effects of environmental tobacco smoke. As a result of this survey, the Peace Corps implemented a smoke-free workplace policy worldwide.

Conclusion Multinational agencies and companies in developing countries should implement policies to restrict smoking, in consultation with their employees.

Services

Corps, 1990 K Street,

NW, Washington, DC, 20526, USA

T R Eng

$T \mathrm{H}$ van der Vlugt

Office on Smoking

and Health, National

Center for Chronic

Disease Prevention

and Health

Promotion, Centers

for Disease Control,

1600 Clifton Road,

NE, Mailstop K-50,

Atlanta, Georgia,

USA

S L Emont

Correspondence to Dr Eng.

Reprint requests to: Dr Emont.

\section{Introduction}

The World Health Organisation estimates that during the 1990s three million people will die every year as a direct result of smoking related illnesses and that about a third of these deaths will occur in developing countries. ${ }^{1}$ The number of deaths that result from exposure to environmental tobacco smoke (ETS) in developing countries is not known but in the United States ETS is associated with approximately 3800 deaths in non-smokers a year. ${ }^{2}$ ETS has recently been classified as a potential occupational carcinogen in the United States, and workplaces are considered to be a potential major source of exposure. ${ }^{3}$
Policies that restrict smoking in public places and workplaces have increased worldwide in recent years. ${ }^{4}$ For example, in the United States the prevalence of workplace policies increased from $36 \%$ to $85 \%$ of companies from 1986 to $1991 .^{5}$ Recent surveys have found that over $90 \%$ of Americans support restrictions on smoking at workplaces. ${ }^{67}$ Strong support has also been documented from other developed countries, such as Australia, where $76 \%$ of public service employees approved of a recent ban on smoking at their place of work. ${ }^{8}$ However, limited data exist on the prevalence of workplace policies in developing countries ${ }^{910}$ and, to our knowledge, there are no published studies that describe the attitudes of people from developing countries on restricting smoking at work.

The Peace Corps is an international development agency sponsored by the United States government which has more than 6000 volunteers in approximately 70 developing countries. In addition to its headquarters in Washington, DC, the Peace Corps has field offices in approximately 60 countries that provide training and administrative support to volunteers. In most countries the corps maintains a main office, a separate training centre, and a medical office. The Peace Corps headquarters was designated a smoke-free workplace in July 1988 .

We report on a survey of attitudes on restricting smoking at the workplace among overseas staff of the Peace Corps, who are primarily host country nationals from more than 50 developing countries. At the time of the survey the corps employed approximately 900 full time staff (approximately $75 \%$ of whom were host country nationals) in 58 overseas officers that provided field support to volunteers in 67 countries. Some preliminary

\section{Methods}

During February and March 1991 all overseas full time staff in the Peace Corps were surveyed by post about cigarette smoking and their opinions on a possible smoke-free workplace policy for Peace Corps offices worldwide. The survey offered anonymity to respondents and completed surveys were not disclosed to incountry staff. Spanish and French translations of the survey were pilot tested in native speakers and were provided to staff in Spanish 
and French speaking countries. In addition, the directors of all overseas officers were surveyed about the type of existing restrictions on smoking and the number of complaints about exposure to ETS that they had received, if any, at the workplace.

The survey of staff elicited information on smoking behaviour and attitudes about a smoke-free workplace policy and exposure to ETS at work. The potential association between attitudes about smoking restrictions and smoking status, educational level, country of origin (developing $v$ developed), and region of origin (for staff from developing countries) were examined. For the purposes of this study Eastern European countries were considered to be developing countries. A current smoker was defined as a person who had smoked at least 100 cigarettes in his or her lifetime and was currently smoking. A former smoker was defined as a person who had smoked at least 100 cigarettes in his or her lifetime and had stopped smoking. People who did not answer a specific question were excluded from the denominator of respondents of the respective question.

The $\chi^{2}$ test was used to compare smoking prevalence, opinions on smoking restrictions, and awareness of the health effects of ETS by various demographic characteristics. Yates's correction for continuity was used with two by two $\chi^{2}$ tests. In addition, the $\chi^{2}$ test for trend was used to examine potential differences in staff attitudes by educational status. The Mantel-Haenszel summary $\chi^{2}$ statistic was calculated for stratified analysis with potentially confounding variables. The KruskalWallis one way analysis of variance was used to examine potential differences in cigarette consumption by region of origin.

\section{Results}

PRE-EXISTING RESTRICTIONS ON SMOKING AT THE WORKPLACE

Before the survey of Peace Corps staff policies restricting smoking at field offices were implemented at the discretion of each office director. The survey of office directors showed that $45 \%(23)$ of 51 offices limited smoking to specific areas, $24 \%$ (12) already had smokefree workplace policies, and $31 \%$ (16) had no restrictions on smoking. There was no significant regional difference in the proportion of offices that restricted smoking-that is, $82 \%$ of central and South American offices, $70 \%$ of Asian and South Pacific offices, $68 \%$ of African offices, and $67 \%$ of Eastern European offices. Most policies that limited smoking banned smoking in common areas such as conference rooms but allowed smoking in individual offices. Twenty six per cent $(14 / 53)$ of office directors received at least one complaint about exposure to tobacco smoke at the workplace during 1990; the median number of complaints received was three (range 1 to 10 ).

RESPONDENTS TO STAFF SURVEY

Ninety one per cent (53) of 58 Peace Corps offices responded to the staff survey. Of 879 full time staff in the 53 offices, $74 \%$ (652) returned completed surveys. Seventy three per cent of the respondents were from developing countries and $27 \%$ were from developed countries. Of respondents from developed countries, $89 \%$ were Americans. The median age of respondents was 37 years (range 18 to 72 ), $52 \%$ were men, the median number of years of formal education received was 16 years (range 0 to 26), and the median number of years of employment in the Peace Corps was four (range $<1$ to 19 ). Comparable data on non-respondents were not available.

\section{SMOKING BEHAVIOUR}

Fifty eight per cent, $21 \%$, and $21 \%$ of 641 respondents were never, former, and current smokers, respectively (table 1). The prevalence of current smokers was not significantly different between the staff from developing $(22 \%)$ and developed countries $(17 \%)\left(\chi^{2}=\right.$ 1.88 , df $=1, p=0 \cdot 17$ ). Among staff from developing countries the highest prevalence of current smokers was found in Africa (27\%), followed by Asia and the Pacific Islands (20\%), Central and South America (19\%), and Eastern Europe $(10 \%)\left(\chi^{2}=3.86, \mathrm{df}=3, \mathrm{p}=0.28\right)$ (table 1).

Current smokers reported that they smoked an average of 12 cigarettes a day (table 1). Among staff from developing countries the mean number of cigarettes smoked a day was 13 for staff from Africa, Asia, and the Pacific Islands, 8 for those from Central and South America, and 7 for those from Eastern Europe (Kruskal-Wallis $\mathrm{H}=6.76, \mathrm{df}=3, \mathrm{p}=0.08$ ). Sixty eight per cent of the 104 current smokers from developing countries reported smoking

Table 1 Prevalence of current smokers and daily consumption of cigarettes among Peace Corps staff by country and region of origin

\begin{tabular}{|c|c|c|c|c|}
\hline \multirow[b]{2}{*}{ Origin } & \multirow[b]{2}{*}{ No of staff* } & \multirow{2}{*}{$\begin{array}{l}\text { No (\%) of } \\
\text { current smokers }\end{array}$} & \multicolumn{2}{|c|}{ Cigarettes a day } \\
\hline & & & Mean $(S D)$ & Range \\
\hline All staff & 641 & 21 & $12.0(9.5)$ & $<1-50$ \\
\hline $\begin{array}{l}\text { Country of origin: } \\
\text { Developing } \\
\text { Developed }\end{array}$ & $\begin{array}{l}465 \\
176\end{array}$ & $\begin{array}{l}22 \\
17\end{array}$ & $\begin{array}{l}11.5(8.7) \\
14.1(11.7)\end{array}$ & $\begin{array}{l}<1-50 \\
<1-40\end{array}$ \\
\hline $\begin{array}{l}\text { Region of origint: } \\
\text { Africa } \\
\text { Central and South America } \\
\text { Asia and Pacific Islands } \\
\text { Eastern Europe }\end{array}$ & $\begin{array}{r}192 \\
159 \\
105 \\
10\end{array}$ & $\begin{array}{l}27 \\
19 \\
20 \\
10\end{array}$ & $\begin{array}{l}12 \cdot 7(9 \cdot 0) \\
8 \cdot 1(5 \cdot 8) \\
13 \cdot 4(10 \cdot 2) \\
7 \cdot 0(0)\end{array}$ & $\begin{array}{r}1-50 \\
1-20 \\
<1-40 \\
7\end{array}$ \\
\hline
\end{tabular}

* Excluding people who did not answer the question or for whom the characteristic was not known.

$t$ Peace corps staff from developing countries. 
American brands of cigarettes compared with $90 \%$ of the 30 smokers from developed countries (mostly Americans) $\left(\chi^{2}=4.54, \mathrm{df}=\right.$ $1, \mathrm{p}=0.03)$.

The median age at starting smoking was 20 years (range 3 to 38 ) for both staff from developing and developed countries. Two people reported starting smoking at 3 years of age and another person at 4 years of age. Two of these staff members were from Africa and the other was from Asia; more information was not available because the survey was anonymous.

Eighty three per cent of 132 current smokers reported at least one attempt to stop smoking in the previous year, and $73 \%$ wanted to stop immediately or in the near future.

\section{OPINIONS ON RESTRICTING SMOKING AT THE} WORKPLACE

Overall, $81 \%$ of 633 respondents were supportive of a smoke-free policy at the workplace (table 2). Support was strong among current smokers $(67 \%)$, staff from developing countries $(78 \%)$, and staff with lower educational levels $(68 \%)$. Significant differences in support for a smoke-free policy were found when staff were grouped by their smoking status, country of origin (developing $v$ developed), years of formal education, and region of origin (table 2 ). When stratified by educational level, however, there was no significant difference in support between staff from developing and developed countries (Mantel-Haenszel summary $\left.\chi^{2}=1 \cdot 24, p=0 \cdot 27\right)$. In addition, when the comparison between the regions of origin was stratified for educational level significant differences between the regions disappeared except in the lowest educational level $(\leqslant 12$ years). Among staff in this educational level, staff from Africa had a lower level of support $(63 \%)$ for a smoke-free policy compared with those from other regions $(91 \%)\left(\chi^{2}=15 \cdot 24\right.$, $\mathrm{df}=1, \mathrm{p}=0.002$ ).

Ninety per cent of staff from offices that had pre-existing smoking restrictions were supportive of a smoke-free policy compared with $82 \%$ of staff from offices that did not restrict smoking $\left(\chi^{2}=5.79, p=0.02\right)$. However, no information was available on attitudes of staff before the various smoking restrictions were implemented in each office.

Among current smokers, those who smoked more cigarettes per day were less likely to support a smoke-free policy. For example, $87 \%$ of smokers who smoked 15 or fewer cigarettes a day supported such a policy compared with only $43 \%$ of smokers who smoked 26 or more a day $\left(\chi^{2}\right.$ test for trend $=8 \cdot 14, p=$ $0.004)$. To examine if the higher prevalence of cigarette smoking among African staff could explain their lower level of support for a smoke free policy, we excluded smokers from analysis and found that non-smoking staff from Africa were still significantly less likely to support such a policy compared with non-smokers from other developing countries $(80 \% v 91 \%$, respectively; $\chi^{2}=7 \cdot 57, \mathrm{p}=0.006$ ).

A ban on smoking in areas where nonsmokers must work was supported by $87 \%$ of staff and was consistently high regardless of smoking status or demographic characteristics. For example, $86 \%$ of staff from developing countries and $82 \%$ of staff with lower educational levels ( $\leqslant 12$ years) supported a ban. Although support for banning smoking in these areas was significantly lower among current smokers compared with those who never smoked and former smokers, $75 \%$ of current smokers supported such a restriction $\left(\chi^{2}=23.37, \mathrm{df}=2, \mathrm{p}=0.000008\right)$.

Overall, $52 \%$ of 598 staff disagreed with the statement "smokers have a right to smoke at work" and $36 \%$ agreed ( $12 \%$ had no opinion). There was no significant difference between the proportion of staff from developing and developed countries who disagreed with this statement $\left(\chi^{2}=1 \cdot 27, \mathrm{df}=1, \mathrm{p}=0 \cdot 26\right)$. An overwhelming proportion $(90 \%$ of 622 staff agreed that "smokers should not smoke when non-smokers are present"; an equal propor-

Table 2 Opinion on a smoke-free workplace policy among Peace Corps field staff by characteristics of staff. Question: "Do you support or oppose a smoke-free worksite policy?"

\begin{tabular}{|c|c|c|c|c|c|}
\hline \multirow[b]{2}{*}{ Characteristic } & \multirow[b]{2}{*}{ No of staff* } & \multicolumn{2}{|c|}{$\begin{array}{l}\text { Percentage of staff who } \\
\text { strongly or somewhat: }\end{array}$} & \multirow{2}{*}{$\begin{array}{l}\text { Percentage with } \\
\text { no opinion }\end{array}$} & \multirow[b]{2}{*}{$p$ value $\dagger$} \\
\hline & & Support & Oppose & & \\
\hline All staff & 633 & 81 & 11 & 8 & NA \\
\hline $\begin{array}{l}\text { Smoking status: } \\
\text { Never smoked }\end{array}$ & 357 & 82 & 12 & 6 & 0.04 \\
\hline Smokers: & & & & & \\
\hline $\begin{array}{l}\text { Former } \\
\text { Current }\end{array}$ & $\begin{array}{l}135 \\
130\end{array}$ & $\begin{array}{l}89 \\
67\end{array}$ & $\begin{array}{r}7 \\
15\end{array}$ & $\begin{array}{r}4 \\
18\end{array}$ & \\
\hline Country of origin: & & & & & \\
\hline $\begin{array}{l}\text { Developing } \\
\text { Developed }\end{array}$ & 463 & 78 & 13 & 9 & 0.02 \\
\hline Formal education (years) $\ddagger:$ & & & & & \\
\hline$\underset{13-16}{\leqslant}$ & $\begin{array}{l}133 \\
199\end{array}$ & $\begin{array}{l}68 \\
85\end{array}$ & $\begin{array}{l}17 \\
10\end{array}$ & $\begin{array}{r}14 \\
5\end{array}$ & $0.002 \|$ \\
\hline$\geqslant 17$ & 238 & 87 & 7 & 6 & \\
\hline $\begin{array}{l}\text { Region of origing: } \\
\text { Africa } \\
\text { Central and South America } \\
\text { Asia and Pacific Islands } \\
\text { Eastern Europe }\end{array}$ & $\begin{array}{r}196 \\
158 \\
99 \\
10\end{array}$ & $\begin{array}{l}68 \\
91 \\
78 \\
80\end{array}$ & $\begin{array}{r}18 \\
5 \\
17 \\
0\end{array}$ & $\begin{array}{r}14 \\
4 \\
5 \\
20\end{array}$ & 0.0004 \\
\hline
\end{tabular}

* Excluding people who did not answer the question or for whom the characteristic was not known.

* Excluding people who did not answer the question or for whom the characteristic was not known.

Comparison between proportion supporting versus proportion op
Includes primary, secondary, and university or college education.

Includes primary, secondar
$\chi^{2}=9 \cdot 61$ in test for trend.

$\chi^{2}=9 \cdot 61$ in test for trend.
Peace Corps staff from developing countries. 
Table 3 Awareness of adverse health effects of exposure to environmental tobacco smoke at the workplace among Peace Corps field staff. Question: "Do you think that the smoke you are exposed to from other people at work is harmful to your health?"

\begin{tabular}{|c|c|c|c|c|}
\hline \multirow[b]{2}{*}{ Characteristic } & \multirow[b]{2}{*}{ No of staff* } & \multicolumn{2}{|c|}{ Percentage of staff } & \multirow[b]{2}{*}{$p$ value $\dagger$} \\
\hline & & Yes & $\begin{array}{l}\text { No or } \\
\text { don't know }\end{array}$ & \\
\hline All staff & 612 & 74 & 26 & NA \\
\hline \multicolumn{5}{|l|}{ Smoking status: } \\
\hline Smokers: & 341 & 18 & 23 & 0.01 \\
\hline $\begin{array}{l}\text { Former } \\
\text { Current }\end{array}$ & 129 & 75 & 25 & \\
\hline \multicolumn{5}{|l|}{ Country of origin: } \\
\hline $\begin{array}{l}\text { Developing } \\
\text { Developed }\end{array}$ & $\begin{array}{l}452 \\
160\end{array}$ & $\begin{array}{l}73 \\
76\end{array}$ & $\begin{array}{l}27 \\
24\end{array}$ & 0.49 \\
\hline \multicolumn{5}{|l|}{ Formal education (years) $\ddagger$ : } \\
\hline $\begin{array}{l}\leqslant 12 \\
13-16 \\
\geqslant 17\end{array}$ & $\begin{array}{l}132 \\
190 \\
171\end{array}$ & $\begin{array}{l}72 \\
74 \\
78\end{array}$ & $\begin{array}{l}28 \\
26 \\
22\end{array}$ & 0.33 \\
\hline \multicolumn{5}{|l|}{ Region or origin $\|$ : } \\
\hline $\begin{array}{l}\text { Africa } \\
\text { Central and South America } \\
\text { Asia and Pacific Islands } \\
\text { Eastern Europe }\end{array}$ & $\begin{array}{r}188 \\
153 \\
101 \\
10\end{array}$ & $\begin{array}{l}64 \\
82 \\
75 \\
80\end{array}$ & $\begin{array}{l}36 \\
18 \\
25 \\
20\end{array}$ & 0.002 \\
\hline
\end{tabular}

* Excluding people who did not answer the question of for whom the characteristic was not known.

+ Calculated by the $\chi^{2}$ test except when indicated.

Includes primary, secondary, and university or college education.

Peace Corps staff from developing countries.

tion of staff from developing and developed countries agreed with this statement.

\section{OPINIONS ON AND EXPOSURE TO ETS AT THE} WORKPLACE

Seventy four per cent of 612 respondents believed that the smoke that they were exposed to from other people at work was harmful to their health (table 3). Current smokers were less likely to agree that ETS was harmful to their health $(64 \%)$ compared with those who never smoked $(78 \%)$ and former smokers $(75 \%)\left(\chi^{2}=8.86, \mathrm{df}=2, \mathrm{p}=0.01\right)$. There was no significant difference, by country of origin or educational level, in the proportion of staff who believed that ETS was harmful to their health (table 3 ). When grouped by region of origin, however, a smaller proportion of staff from Africa believed that ETS was harmful compared with those from other regions $\left(64 \%\right.$ v $\left.79 \%, \chi^{2}=12.98, \mathrm{p}=0.0003\right)$. Among staff in the lowest educational level ( $\leqslant 12$ years) the proportion of African staff who believed that ETS was harmful was still significantly lower than that among nonAfrican staff $\left(\chi^{2}=4.97, \mathrm{df}=1, \mathrm{p}=0.03\right)$.

Fifty one per cent of 640 respondents reported that they were rarely or never exposed to cigarette smoke at the workplace and $49 \%$ that they were sometimes, frequently, or always exposed. In addition, $88 \%$ of 632 staff reported that their work area was usually not smoky at all or not very smoky and $12 \%$ that the workplace was usually somewhat smoky or very smoky. Eighty one per cent of 636 staff considered the smoke from someone else's cigarette to be very annoying or somewhat annoying, and $19 \%$ considered it to be not annoying at all.

\section{Discussion}

As a result of overwhelming support for a smoke-free workplace policy among Peace
Corps staff, a smoke-free workplace policy was implemented in all overseas offices on 1 September 1991. The Peace Corps was the first United States government agency to provide a smoke-free environment for its offices worldwide.

Data on the prevalence and enforcement of restrictions on smoking at workplaces are not available for most developing countries. The data that are available indicate that few countries have laws that restrict smoking in public places and a lesser number have regulations at worksites. ${ }^{910}$ In both developed and developing countries, however, there seems to be an increasing trend in regulating smoking in public places and workplaces. ${ }^{12}$ Preventing exposure to ETS is of particular importance in developing countries because substantial exposure to tobacco smoke may occur at home and at work because of the relative lack of restrictions on smoking ${ }^{910}$ and the higher prevalence of smoking in these countries ${ }^{9}$ compared with developed countries.

To our knowledge, no published studies have examined the attitudes of workers in a large number of developing countries on smoking restrictions in workplaces. In our study support for a smoke-free worksite policy and banning smoking where non-smokers work were consistently high in almost all countries and among all types of staff. Consistent with other data, ${ }^{13}$ support for a smokefree policy was positively associated with educational level.

Most employees and management staff are supportive of workplace smoking policies after they are implemented. ${ }^{14}$ Workplace policies are more likely to be implemented in places where there is strong support among employees for restricting smoking. ${ }^{15}$ In this survey, because no previous information on attitudes of Peace Corps staff was available, it is unclear whether the higher level of support for a smoke-free policy among staff from offices with pre-existing policies resulted after such 
policies were implemented or whether these offices implemented such policies as a result of strong support among staff.

The extremely high rate of support for a smoke-free workplace policy among Peace Corps staff may not reflect the attitudes of other host country nationals, primarily because corps staff are generally better educated and have more access to health information compared with other host country nationals. The Peace Corps may recruit staff with similar values or host country nationals may adopt American values during their employment with the corps. Indeed, the prevalence of smoking among host country national Peace Corps staff is substantially less than that expected for most developing countries. ${ }^{9}$ Further studies on the prevalence, knowledge, attitudes, and practices of residents of developing countries regarding cigarette smoking need to be conducted in order to address the barriers to reducing smoking in developing countries. ${ }^{16}$

Most of the Peace Corps staff surveyed where aware of the harmful effects of ETS. This level of awareness of ETS is probably higher for host country national Peace Corps staff compared with that among other host country nationals. People in developing countries need to be informed of the adverse health effects of cigarette smoking and involuntary exposure to tobacco smoke.

Compared with other regions, support for a smoke-free workplace policy and awareness of the harmful effects of ETS was lowest among staff from Africa. In addition, the prevalence of smoking and consumption of cigarettes per smoker was highest in Africa. These data suggest that Africans, especially those of lower educational status, may be the least informed of the health risks associated with smoking compared with people from other developing areas.

The proportion of staff from developing countries who regularly smoke American brands of cigarettes was high and may reflect the increased promotion of cigarettes in developing countries by American and multinational tobacco companies. ${ }^{10}$ This finding may also reflect, to some extent, the preference and access of host country national Peace Corps staff to American cigarettes.

Most survey respondents from developing countries disagreed that smokers have a right to smoke at work and agreed that smokers should not smoke in the presence of nonsmokers. In addition, many comments from staff from developing countries indicated that they believed that smokers who expose nonsmokers to cigarette smoke were insensitive to the people around them.

The results of this survey document overwhelming support among Peace Corps staff for restricting smoking at corps workplaces. Multinational, as well as host country, agencies and companies in developing countries should assess the attitudes of their employees about restricting smoking at the workplace, provide education and other help in stopping smoking, and implement policies to restrict smoking in consultation with their employees.

Multinational agencies and companies from developed countries should have a standard of occupational health and safety for their international workplaces that is similar to that for their domestic workplaces. In addition to the substantial economic benefits to employers gained by reducing smoking among employees, ${ }^{17}$ the implementation of policies to restrict smoking at workplaces by such agencies and companies can create a positive environment for employee health promotion, engender a positive image of the employer among its workers and in the community, and act as a positive role model for other agencies and companies, both international and national.

We thank Toni Dumas, Michael Eschleman, Carol Herrera, Amparo Kunze, Cecilia Otero, Dr Allen Webb, and Anne Wilson for translating surveys. In addition, we thank all Peace Corps country directors, medical officers, former director Paul Coverdell, Jody Olsen, Collins Reynolds, Laverne Dees Webb, and other Peace Corps staff who assisted with this survey and implemented the Peace Corps' smoke-free policy.

1 World Health Organisation. Tobacco alert: WHO Programme on Tobacco or Health. Geneva, Switzerland: gramme on Tobacco or Health.
World Health Organisation, 1991.

2 National Research Council. Environmental tobacco smoke: measuring exposures and assessing health effects. Washington, DC: National Academy Press, 1986.

3 US Department of Health and Human Services. Environmental tobacco smoke in the workplace: lung cancer and other health effects. US Department of Health and Human Services, Public Health Service, Centers for Disease Control, National Institute for Occupational Safety and Health, 1991. (Current Intelligence Bulletin 54.)

4 World Health Organisation. World No-Tobacco Day, 31 May 1991. Public places and transport: better be tobaccofree. Geneva, Switzerland: WHO, 1991.

5 Bureau of National Affairs. Smoking in the workplace : 1991. Washington, DC: Bureau of National Affairs, 1991. Bulletin to Management BNA, Policy and Practice (Bulletin to Management BNA, Po
Series. SHRM-BNA Survey No 55.)

6 Centers for Disease Control. Public attitudes regarding limits on public smoking and regulation of tobacco sales and advertising-10 U.S. communities, 1989. MMWR $1991 ; 40: 344-5,351-3$.

7 Gallup. Many Americans favour restrictions on smoking in public places. Princeton, New Jersey: Gallup Organisation, 1990. (Gallup Report No 298.)

8 Borland R, Owen N, Hill D, Chapman S. Staff members' acceptance of the introduction of workplace smoking bans in the Australian public service. Med $\mathcal{F}$ Aust $1989^{\circ}$. 151: $525-8$.

9 Chapman S, Leng WW. Tobacco control in the third world: a resource atlas. Penang, Malaysia: International world: a resource atlas. Penang, Malaysia: Internation

10 Council on Scientific Affairs. The worldwide smoking epidemic: tobacco trade, use, and control. $\mathcal{F} A M A 1990$; epidemic: tobac

11 Centers for Disease Control. Establishment of smoke-free offices worldwide - U.S. Peace Corps. $M M W R$ 1991; 40: 343-4.

12 Roemer R. Recent developments in legislation to combat the world smoking epidemic. World Health Organisation, Division of Noncommunicable Diseases, Smoking and Health Programme, 1986.

13 US Department of Health and Human Services. Tobacco use in 1986 : methods and basic tabulations from adult use of tobacco survey. Public Health Service, Centers for Disease tobacco survey. Public Health Service, Centers for Disease Control, Office on Smoking and Health.

14 Sorenson G, Rosen A, Pinney J, Rudolph J, Doyle N. Work-site smoking policies in small businesses. $\mathcal{f}$ Occup Med 1991; 33: 980-4.

15 Bureau of National Affairs. Where there's smoke: problems and policies concerning smoking in the workplace. 2nd ed. Washington, DC: Bureau of National Affairs, 1987

16 Pierce JP. Progress and problems in international public health efforts to reduce tobacco usage. Ann Rev Public Health 1991 ; 12: 383-400.

17 Fielding JE. Banning worksite smoking. Am $f$ Public Health 1986; 76: 957-9. 


\section{Translations \\ of abstract}

Soutien pour des restrictions au tabagisme sur les lieux de travail dans les pays en voie de développement: une enquête auprès du personnel du Peace Corps

Thomas R Eng et al

\section{Résumé}

Objectif: Observer les habitudes tabagiques et les attitudes du personnel du Peace Corps face aux restrictions au tabagisme sur leur lieux de travail dans les pays en voie de développement.

Méthode: Enquête postale anonyme auprès de l'ensemble du personnel à plein temps du Peace Corps (environ 900 personnes) dans 58 pays.

Matériel utilisé: Questionnaires renvoyés par 652 employés à plein temps; $73 \%$ étaient des ressortissants de plus de 50 pays en voie de développement accueillant le Peace Corps.

Bases d'évaluation: Prévalence du tabagisme, soutien pour une politique de lieux de travail sans tabac, et prise de conscience de l'effet nocif de la fumée de tabac ambiante sur la santé.

Résultats: Globalement, $81 \%$ des personnes interrogées sont favorables à une politique de lieux de travail sans tabac, y compris $\mathbf{7 8} \%$ du personnel des pays en voie de développement, $67 \%$ des fumeurs, et $68 \%$ des membres du personnel qui ont un niveau d'enseignement inférieur. D'importantes différences dans le soutien à une politique anti-tabac ont été observées en fonction du regroupement du personnel selon les critères suivants: habitudes tabagiques, pays d'origine (développé - en voie de développement), niveau d'études et région d'origine. En outre, $74 \%$ du personnel était conscient des effets nocifs de la fumée de tabac dans l'air ambiant. Suite à cet enquête, le Peace Corps a mis en place dans le monde entier une politique pour des lieux de travail sans tabac.

Conclusions: Les organisations et entreprises multinationales dans les pays en voie de développement devraient mettre en place, tout en consultant les employés, des politiques de restriction du tabagisme sur le lieu de travail.
Apoyo para restringir el consumo de cigarrillo en los lugares de trabajo en países en desarrollo: una encuesta del personal del Cuerpo de Paz

Thomas R Eng et al

\section{Resumen}

Objetivo: Estudiar los hábitos del tabaquismo y las actitudes del personal del Cuerpo de Paz en cuanto a restricciones del uso del cigarrillo en lugares de trabajo, en los países en desarrollo.

Diseño: Encuesta postal anónima de todos los funcionarios a tiempo completo del Cuerpo de Paz (n calculado $=900$ ) en 58 países.

Sujetos: Entre 652 empleados a tiempo completo que contestaron los cuestionarios; $73 \%$ eran ciudadanos del país anfitrión, de más de 50 países en desarrollo.

Principales resultados obtenidos: Prevalencia del tabaquismo, apoyo a una política para eliminar el tabaquismo en los lugares de trabajo, y toma de conciencia sobre los efectos adversos del tabaco para la salud y el medio ambiente.

Resultados: Considerados globalmente, $81 \%$ de los encuestados apoyaban un lugar de trabajo sin tabaco, incluyendo $78 \%$ de los funcionarios de los países en desarrollo, $67 \%$ de los fumadores actuales, y $68 \%$ del personal con menores niveles de educación. Se encontraron diferencias significativas en cuanto al apoyo a una política contra el tabaquismo en los lugares de trabajo, cuando los empleados se agrupaban por fumadores o no fumadores, país de origen (en desarrollo vs. desarrollado), años de educación formal, y regíon de origen. Además $74 \%$ del personal conocía los efectos perjudiciales del tabaco en el ambiente. Como resultado de esta encuesta, el Cuerpo de Paz adoptó una política de lugares de trabajo libres de humo en todo el mundo. Conclusión: Los organismos multinacionales y las empresas de los países en desarrollo deberían, en consulta con sus empleados aplicar políticas para restringir el uso del tabaco.

\section{发展中国家对在工作场所限制吸烟政策的支持：对和平队队员的调查 汤姆・伍等}

目标: 调查和平队队员的吸烟行为及他们对在工作场所限制吸烟政策的态度.

设计：在 58 个国家中，对 900 名所有全日制和平队队员进行不记名信函的调查。

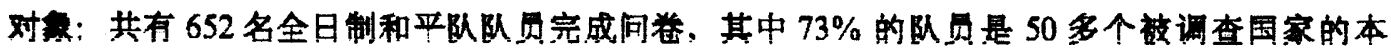
地人.

主夏指标：吸烟率，对工作场所无烟政策的支持率，认识被动吸烟危富的比率。

结果: 无烟工作场所政策的总支持率是 $81 \%$, 发展中国家队负的支持率是 $78 \%$, 目前吸姻队员 的支持率是 $67 \%$,文化程度较低的支持率为 $68 \%$ 。当将队员按吸烟现状，是发展中国家还是 发达国家、受正规数育年数及出生地分组时，它们之间对限制吸烟政策的支持高存在显著性 差异. 出外, $74 \%$ 的队贝知道被动吸烟的危害. 通过这次调查, 全世界所有和半队都实行了 无烟工作场所的政策。

结论：在发展中国家的多国机构和公司，应通过与主主协店以实行限制吸烟的政策. （中国倩康数育研究所烟草控制研究室 郑保义 译） 